\title{
Kosovo er stadig et internationalt protektorat
} Vibeke Sperling

\author{
Trods de ekstraordinært store summer, som EU \\ har postet i Kosovo, er det stadig Vestbalkans \\ fattigste og mest isolerede land
}

Lidt over 100 kroner om måneden er hvad 150.000 borgere i Kosovo får i understøttelse, viste en ny statistik fra Institut for Socialpolitik i Pristina i februar. Det betyder ifølge den ledende avis Koha Ditore, at den gruppe er i en endnu værre situation end dem på den officielle grænse for 'ekstrem fattigdom', der har et par hundrede kroner til rådighed om måneden.

Det skal især i hovedstaden Pristina sammenholdes med et prisniveau, der er presset i vejret af de mange udlændinge og lokale, som arbejder for de internationale organisationer i byen.

Koha Ditore citerer en medarbejder ved Institut for Socialpolitik for at sige, at tusinder "drømmer om i det mindste at leve på den ekstreme fattigdomsgrænse".

Ifølge rapporten får seks procent af 34.000 adspurgte familier på so- cialhjælp end ikke penge nok til den nødvendige medicin. 20 procent oplyste, at socialhjælpen kun dækker de mest basale behov i ti dage hver måned. Andre 20 procent får hjælpen til at strække halvdelen af måneden.

Og med en arbejdsløshed på 40 procent og langt højere for de unge ryger de i forvejen dårligst stillede bagerst i køerne efter arbejde. Generelt er der få tegn på fremgang $\mathrm{i}$ $\varnothing$ konomien. Det forhold at der stadig er usikkerhed om Kosovos status holder internationale investorer væk. Og Kosovo trådte ind på scenen som selvstændig stat på et tidspunkt, hvor den globale krise slog igennem og mindskede viljen til at gå ind på nye markeder.

\section{Alene til fødselsdag}

De færreste lagde mærke til, at Ko- 
sovo i februar fyldte to år som selvstændig stat. Og reelt er det stadig kun en quasi-stat som fortsat internationalt protektorat.

17. februar 2008, da Kosovo erklærede sig selvstændigt, var verdenspressen massivt til stede. En hel del kom også til fødselsdag sidste år, men i år syntes dagen glemt af omverdenen. I Kosovos markedsføring af sig selv fremhæves, at landet har Europas yngste befolkning med en gennemsnitsalder på 25 år. "Det giver landet en ånd af optimisme og foretagsomhed, som I ikke finder andre steder. I kan mærke den positive energi, der gennemstrømmer befolkningen. Alt er muligt", hed det i en officiel annonce op til fødselsdagen.

Det er dog småt med positiv energi blandt de mange borgere i Kosovo uden udsigt til arbejde.

Kosovo er reelt kun en klar succeshistorie for det, som ikke skete. Serbiens og Ruslands forudsigelser om, at selvstændigheden ville bringe nye blodigheder både i Kosovo og andre steder i Europa, blev gjort til skamme. Men kaos hersker.

\section{Flere serbere stemmer}

Der er spredte fremskridt for sameksistensen imellem serbere og albanere. Ved lokalvalg sidste efterår deltog relativt flere serbere for eksempel end i noget valg hidtil, men stadig kun et mindretal, fordi Beograd opfordrer dem til at boykotte valg.
15 procent af Kosovos territorium, nord for floden Ibar i og omkring Mitrovica er helt uden for centralmagtens kontrol og styret af selvkørende serbiske paralleladministrationer for de 120.000 serbere i området.

Serberne anerkender ikke EUmissionen EULEX, der sidste sommer skulle have overtaget fra $\mathrm{FN}-\mathrm{ad}-$ ministrationen UNMIK. Men UNMIK er der stadig og det eneste udenlandske organ, som de radikale serbere vil snakke med. Den internationale tilstedeværelse er som en blæksprutte med mange arme.

EU's særlige repræsentant, Pieter Feith, har alene to arme, da han også er chef for det Internationale Kontor (ICO). Europa-kommissionen har sit eget kontor, og EU har missionen EULEX. Dertil kommer OSCE og de fredsbevarende styrker KFOR med Europas næststørste Nato-base. De leger alle i samme sandkasse, men ofte uden at vide, hvad den anden gør.

Peter Feiths mandat blev for nylig forlænget til 31. august. Det skete næsten uden debat på et møde for EU's indenrigs- og justitsministre, efter at udenrigsministrene havde forlænget stort set alle andre EU-missioner med et halvt år.

Men EU's mission i Kosovo er ikke som de andre. EULEX er EU's hidtil største og mest prestigefyldte mission, men den stadig ringere opmærksomhed omkring den afspejler trætheden i EU med hele Vestbal- 
kan. Derudover er missionen i Kosovo som alle andre ramt af problemerne med at få den nye EU-udenrigstjeneste på plads under baronesse Ashton.

Og EU-trætheden om Vestbalkan er særlig udtalt i Kosovo, da fem EUlande stadig ikke anerkender Kosovos selvstændighed. Spanien, som er det vigtigste modstanderland og nu EU-formandsland, har krævet klart svar fra Feith om, hvordan han vil sikre EU's neutralitet om Kosovos status. Feith sidder nemlig med det dilemma, at løftet om neutralitet var den eneste måde at få alle EU-landes opbakning til EULEX. Samtidig er hele konstruktionen de facto baseret på tidligere FN-mægler Martii Ahtisaaris plan for 'overvåget selvstændighed'. Miroslav Lajeak, udenrigsminister i Slovakiet, der er blandt landene, der nægter at anerkende Kosovo, satte kniven i såret, da han i marts krævede, at Feith skal garantere EU's neutralitet i spørgsmålet om Kosovos status.

Den store modsætning er, at EU's og USA's aftaler med Kosovos regering netop er baseret på Ahtisaari Planen, som Kosovos regering er forpligtet til, men EU's folk i landet officielt slet ikke må tale om.

\section{Plan for nord}

Modsætningen er yderlige skærpet af, at Feiths kontor i Pristina fx har aftalt en plan med Kosovos regering, der skal bringe det serbisk do- minerede nordlige Kosovo tilbage under Pristinas kontrol. Hertil siger Slovakiets udenrigsminister: "Det er aldrig blevet diskuteret eller godkendt af de relevante europæiske institutioner".

Kosovo sidder fast i en ond cirkel, hvor den manglende retsstat betyder, at embedsmænd misbruger offentlige midler og uden en god økonomi kan den organiserede kriminalitet ikke bekæmpes. Ifølge Kosovos regering vil økonomien vokse på basis af landets store mineralrigdomme og en stadig yngre befolkning. Økonomien ventes at vokse med fire procent i år, men selv det vil være alt for lidt til at rette op på $\varnothing$ konomien. Den årlige per capita indkomst er 13.000 kroner, mens EU-gennemsnittet er 178.000 kroner.

Kosovos største problemer er den fortsat uafklarede status, holdt oppe af genstridige EU-medlemmer, og landets svage økonomi.

Disse to største udfordringer beskæftiger EU-missionen sig ikke med. Har EULEX så opfyldt missionen at gøre Kosovo til en retsstat? Nej, også her er langt igen, selv om der er visse fremskridt i retssystemet. Men problemer er der også mange af for KFOR's bestræbelser på at få en civil lokal sikkerhedsstyrke op at stå. I marts suspenderede Nato sin træning af den 2.500 mand store Kosovo Sikkerhedsstyrke, efter at den ved en mindehøjtidelighed for Kosovos tidligere befrielseshær UCK 
præsenterede en bevæbnet militær styrke. Det er i strid med styrkens mandat.

Trods den fortsatte tilstedeværelse af 10.000 Nato-styrker og 2.000 politifolk dommere og anklagere fra EU forbliver Kosovo "en kilde til og hjemsted for organiseret kriminalitet”, ifølge den seneste EU-kommissionsrapport. De internationale repræsentanter i Kosovo ved, at den er gal, men der har i hvert fald tidligere været set igennem fingrene med det, fordi det er gået ret ublodigt for sig. Og det tilskrives netop samarbejdet imellem underverdenen og lokalstyret, som er en magtdeling imellem ledende klaner, herunder regeringsleder Hashim Thacis.

\section{Isoleret fra omverdenen}

Der var i december sidste år gode nyheder for mange borgere i Vestbalkan, da Makedonien, Serbien og Montenegro blev givet delvis visumfrihed. Det var det bedste, som EU kunne gøre i forbindelse med 20året for murens fald. Debatter i Europa-Parlamentets regi om Europas betydning for forskellige europæiske lande viste, at for borgerne i Vestbalkan er 'frihed til at rejse' det allervigtigste.

Men visumtvang er der stadig for Bosnien og Albanien, som ikke har opfyldt kravene til liberalisering af adgangen til EU. Det menes dog kun at være et spørgsmål om tid, før de kommer med.
Anderledes vanskeligt er det for borgere i Kosovo. Mens EU relativt set har postet flere penge i Kosovos borgere end i nogen anden del af Europa, er det nye europæiske land langt mere isoleret fra omverdenen end de fleste andre. Det nye Kosovo pas giver kun borgerne i det nu fredelige land adgang til fem lande uden visa: Albanien, Montenegro, Makedonien, Tyrkiet og Haiti.

Selv borgere i det krigshærgede Afghanistan har fri adgang til langt flere lande.

Europa-Parlamentet har lagt op til, at der udarbejdes en klar køreplan for visumliberalisering også for kosovorerne. Som Europa-Parlamentet har understreget, er deres isolation helt hen i vejret. Det kan ikke retfærdiggøres med henvisning til det uløste spørgsmål om Kosovos status, som fem EU lande opretholder ved endnu ikke at have anerkendt Kosovo. EU taler jo for eksempel visumliberalisering med Taiwan, som EU af hensyn til Kina ikke anerkender.

I praksis er det albanerne i Kosovo, som forbliver ude i kulden, da serbere fra Kosovo med serbisk pas kun behøver en proforma adresse i Serbien for at nyde godt af visumliberaliseringen for Serbien. Med Serbien næsten helt inde i varmen på visumfronten, tilskyndes serbere $\mathrm{i}$ Kosovo i praksis yderligere til ikke at erhverve sig det nye lands papirer, herunder det nye pas.

Og med den forbedrede situation 
for borgere i Makedonien, Montenegro og Serbien bliver der tale om en ny form for splittelse i Vestbalkan, med borgerne i Kosovo som de allermest isolerede. Det er nok en ringe trøst for dem, at de kan rejse til Haiti!

\section{Europa-Parlamentets forslag}

Europa-Parlamentet har i en rapport givet svar på, hvad der bør gøres: "Kommissionen bør inden for grænser for dens kompetence og $\mathrm{i}$ lyset af resolution 1244 (fra 1999. red.) starte dialog med Kosovo for at udarbejde en køreplan for visa-liberalisering, som den der er etableret med lande i Vestbalkan".

En anerkendelse af Kosovos nye pas vil være et afgørende skridt til den statsopbygning, som er formålet med EULEX i Kosovo. Og erfaringerne viser, at når EU i Vestbalkan har haft klare køreplaner, har fællesskabets indflydelse som blød magt været størst. Det gælder ikke mindst visumfrihed.

Efter Europa-Parlamentets indstilling om at få Bosnien og Albanien på 'den hvide liste' til visumliberalisering er der gode muligheder for, at det kan ske i år. Det samme bør EU gøre alt for, når det gælder Kosovo.

Indtil nu har 65 lande anerkendt
Kosovo, men det er gået stadig langsommere og kun 11 nye kom til i 2009. Serbien fik FN's opbakning til at bede den Internationale Domstol i Haag om at vurdere, hvorvidt Kosovos selvproklamerede selvstændighed var i strid med folkeretten. Det bliver kun en indstilling uden juridisk gyldighed, som ventes afsagt en af de nærmeste måneder. Vurderingen er fra flere uafhængige eksperter, at domstolen ikke vil fælde en ensidig dom. Under alle omstændigheder bringer kendelsen næppe en løsning på striden og dermed næppe en afklaring for Kosovo. Men på positivsiden er, at landet er blevet optaget i flere internationale institutioner som Den Internationale Valutafond (IMF) og Verdensbanken.

Den eneste kontinuerlige officielle kontakt imellem Kosovo og Serbien er på et område, der er vitalt for mange borgere i begge lande: efterforskningen efter de savnede og tilbagelevering af identificerede lig til de efterladte. Der er stadig 1.900 savnede fra Kosovo-krigen 1998-99, heraf 532 serbere. Samarbejdet herom har stået på siden 2002 og viser, at der kan tales sammen, når der er pres på fra almindelige borgere.

Vibeke Sperling er journalist på Politiken og redaktør af Udenrigs. 